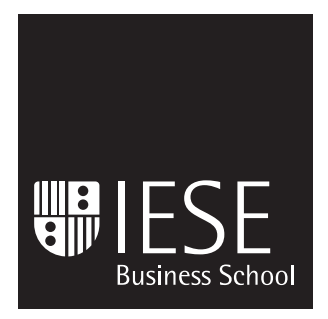

Working Paper

WP no 715

November, 2007

University of Navarra

\title{
A MORE REALISTIC VALUATION: APV AND WACC WITH CONSTANT BOOK LEVERAGE RATIO
}

\author{
Pablo Fernández
}


The CIIF, International Center for Financial Research, is an interdisciplinary center with an international outlook and a focus on teaching and research in finance. It was created at the beginning of 1992 to channel the financial research interests of a multidisciplinary group of professors at IESE Business School and has established itself as a nucleus of study within the School's activities.

Ten years on, our chief objectives remain the same:

- Find answers to the questions that confront the owners and managers of finance companies and the financial directors of all kinds of companies in the performance of their duties

- Develop new tools for financial management

- Study in depth the changes that occur in the market and their effects on the financial dimension of business activity

All of these activities are programmed and carried out with the support of our sponsoring companies. Apart from providing vital financial assistance, our sponsors also help to define the Center's research projects, ensuring their practical relevance.

The companies in question, to which we reiterate our thanks, are:

Aena, A.T. Kearney, Caja Madrid, Fundación Ramón Areces, Grupo Endesa, Royal Bank of Scotland and Unión Fenosa.

http://www.iese.edu/ciif/ 


\title{
A MORE REALISTIC VALUATION: APV AND WACC WITH CONSTANT BOOK LEVERAGE RATIO
}

\author{
Pablo Fernández ${ }^{1}$
}

\section{Abstract}

We value a company that targets its capital structure in book-value terms. This capital structure definition provides us with a valuation that lies between those of Modigliani-Miller (fixed debt) and Miles-Ezzell (fixed market-value leverage ratio).

We show that if a company targets its leverage in market-value terms, it has less value than if it targets the leverage in book-value terms. We also present empirical evidence that permits us to conclude that debt is more related to the book-value of the assets than to their market-value.

${ }^{1}$ Professor, Financial Management, PricewaterhouseCoopers Chair of Finance, IESE

JEL classification: G12; G31; G32

Keywords: value of tax shields, required return to equity, WACC, company valuation, APV, cost of equity. 


\section{A MORE REALISTIC VALUATION: APV AND WACC WITH CONSTANT BOOK LEVERAGE RATIO*}

We value a company when its debt policy is determined by a book-value ratio. We argue that when managers have a target capital structure, it is usually in book-value terms (as opposed to market-value terms), in large part because this is what credit rating agencies pay attention to.

Credit rating is the second most important factor, after the maintenance of financial flexibility, in the decision to issue more debt (Graham and Harvey, 2001). While rating agencies emphasize that both financial and non-financial factors matter, academic literature has focused primarily on the ability of financial ratios to predict ratings. Existing literature (such as Blume, Lim and MacKinlay, 1998) shows us that interest coverage and leverage (two ratios calculated with book values) have the most pronounced effect on credit ratings. These ratios have also been identified by the rating agencies themselves (e.g., Standard and Poor's, 2006) as key determinants of a company's credit rating.

We also provide empirical evidence about the capital structure of companies and find that the constant book-value leverage ratio assumption fits the market data much better than the constant market-value leverage ratio assumption.

Many authors consider that debt policy may only be framed in terms of maintaining a fixed market-value debt ratio or a fixed dollar amount of debt. We develop valuation formulae for companies that maintain a fixed book-value leverage ratio and argue that, for most companies, and especially when calculating residual values, this assumption is more realistic than the two previous ones.

In section 1, we derive the general formula for the value of tax shields. In section 2, we apply this formula to a company that maintains a constant book-value leverage ratio. In section 3, we compare the valuation with that of other financing strategies. In section 4, we calculate the required return to equity and the WACC. Section 5 is a numerical example. In section 6, the correlation between the tax shields and the free cash flow is discussed. Section 7 concludes.

\footnotetext{
* I would like to thank my parents, as they have been my living example of virtues; especially hope and fortitude. I also thank an anonymous referee, Enrique Arzac, José Manuel Campa, Ian Cooper, Javier Estrada, Mark Flannery, John Graham, Yilmaz Guney, Stephen Penman, Scott Richardson, Michael Roberts and Zhaoxia Xu for very helpful comments to earlier manuscripts of this paper, and Rafael Termes for the sharp questioning that encouraged me to explore valuation problems. José M. Carabias did wonderful work as research assistant.
} 


\section{General expression of the value of tax shields}

The value of the debt today $\left(D_{0}\right)$ is the present value of the future stream of interest minus the present value of the future stream of the increases of debt $\left(\Delta D_{t}\right)$ :

$$
D_{0}=\sum_{1}^{\infty} P V_{0}\left[\text { Interest } t_{t}\right]-\sum_{1}^{\infty} P V_{0}\left[\Delta D_{t}\right]
$$

The value of tax shields (VTS) defines the increase in the company's value as a result of the tax saving obtained by the payment of interest, and is the present value of the interest times the tax rate,

$$
V T S_{0}=T \sum_{1}^{\infty} P V_{0}\left[\text { Interest }_{t}\right]=T \cdot D_{0}+T \sum_{1}^{\infty} P V_{0}\left[\Delta D_{t}\right]
$$

Equation (2), valid for perpetuities and for companies with any pattern of growth, shows that, if the tax shields are always deductible and $\mathrm{T}$ applies to all states, the value of tax shields depends only upon the nature of the stochastic process of the net increase of debt, the existing debt $\left(\mathrm{D}_{0}\right)$ and the tax rate $(\mathrm{T}) .{ }^{1}$ We will see that the nature of the stochastic process of the net increase of debt is very different if the debt is proportional to the book-value of equity than if the debt is proportional to the market-value of equity. The riskiness of the increases of debt is smaller in the first case than in the second case and, consequently, the value today of the future stream of the increases of debt is higher.

\section{Valuation of a company whose debt policy is determined by a book-value ratio}

Suppose a company's debt policy is determined by a book-value ratio. In this situation, $\mathrm{D}_{\mathrm{t}}=$ $K \cdot E$, being $D$ the debt, Ebv the book-value of equity, and $A$ is the book-value of assets. $A_{t}=$ $\mathrm{Ebv}_{\mathrm{t}}+\mathrm{D}_{\mathrm{t}}$.

The Free Cash Flow (FCF) is the difference between the Profit After Tax of the unlevered company (PATu), and the increase of the book-value of the assets $(\Delta \mathrm{A}): \mathrm{FCF}_{\mathrm{t}}=\mathrm{PATu}_{\mathrm{t}}-\Delta \mathrm{A}_{\mathrm{t}}$. For a company in a constant risk class we assume that $\mathrm{Ku}$ is the common appropriate discount rate for the expected values of $\mathrm{FCF}_{t}, \mathrm{PATu}_{\mathrm{t}}$ and $\Delta \mathrm{A}_{\mathrm{t}}$.

Then, in a perpetuity growing at a constant rate g, the value of the unlevered company $(\mathrm{Vu})$ may be written as:

$$
V u_{0}=\frac{\mathrm{FCF}_{0}(1+\mathrm{g})}{\mathrm{Ku}-\mathrm{g}}=\frac{\mathrm{P} A T u_{0}(1+\mathrm{g})-\mathrm{gA}_{0}}{\mathrm{Ku}-\mathrm{g}}
$$

The present value of the expected increases of assets is:

$$
\sum_{1}^{\infty} P V_{0}\left[\Delta A_{t}\right]=\mathrm{gA}_{0} /(\mathrm{Ku}-\mathrm{g})
$$

\footnotetext{
1 Booth (2007) discusses situations in which the tax shields are not always deductible and uses a parameter $\gamma$ (a decreasing function of debt) instead of $\mathrm{T}$.
} 
As $A_{t}=E_{b v}+D_{t}$, and $D_{t}=K \cdot E b v_{t}$, then $D_{t}=A_{t} \cdot K /(1+K)$, and:

$$
\sum_{1}^{\infty} P V_{0}\left[\Delta D_{t}\right]=g \mathrm{D}_{0} /(\mathrm{Ku}-\mathrm{g})
$$

Substituting (5) in (2) we get the VTS of a company that maintains a fixed book-value leverage ratio:

$$
V T S_{0}^{D=K E b v}=\frac{\mathrm{D}_{0} \mathrm{Ku} \mathrm{T}}{\mathrm{Ku}-\mathrm{g}}
$$

Although equation (6) may be read as the present value of $\mathrm{D}_{0} \mathrm{KuT}$ growing at $\mathrm{g}$, it does not represent it. Rather, equation (6) is the present value of the tax shields $\left(D_{0} R_{F} T\right)$ growing at a rate $g$ and discounted at a growing rate, being that rate $\mathrm{R}_{\mathrm{F}}$ for $\mathrm{t}=1$. $^{2}$

\section{Valuation of companies under alternative financing strategies}

If the company has a preset amount of debt, $\Delta \mathrm{D}_{\mathrm{t}}$ is known with certainty today and MM applies: the appropriate discount rate for the expected value of $\Delta D_{t}$ is $R_{F}$, the risk-free rate, and

$$
\sum_{1}^{\infty} \mathrm{PV}_{0}\left[\Delta \mathrm{D}_{\mathrm{t}}\right]=\mathrm{gD}_{0} /\left(\mathrm{R}_{\mathrm{F}}-\mathrm{g}\right)
$$

Substituting (7) in (2), we get:

$$
\operatorname{VTS}_{0}^{\mathrm{MM}}=\frac{\mathrm{D}_{0} \mathrm{R}_{\mathrm{F}} \mathrm{T}}{\mathrm{R}_{\mathrm{F}}-\mathrm{g}}
$$

Equation (7) provides a higher value than equation (5) and, consequently, the VTS according to MM is higher than the VTS according to equation (6).

If the company's debt policy is determined by a market-value ratio (instead of a book-value one), then the amount of debt is proportional to the market-value of equity ${ }^{3}$ (E) and the present value of the expected increase of debt in period $t$ (as $D_{t-1}$ is known in period $t-1$ ) is:

$$
P V_{0}\left[\Delta D_{t}\right]=\frac{D_{0}(1+g)^{t}}{(1+K u)^{t}}-\frac{D_{0}(1+g)^{t-1}}{\left(1+R_{F}\right)(1+K u)^{t-1}}
$$

The sum of all the present values of the expected increases of debt is a geometric progression with growth rate $=(1+\mathrm{g}) /(1+\mathrm{Ku})$. Therefore:

$$
\sum_{t=1}^{\infty} P V_{0}\left[\Delta D_{t}\right]=\frac{D_{0}}{K u-g}\left(g-\frac{K u-R_{F}}{1+R_{F}}\right)
$$

\footnotetext{
${ }^{2}$ Equation (6) is equal to equation (28) in Fernández (2004), to equation (4) in Booth (2007), and to equation (11) in Massari, Roncaglio and Zanetti (2007).

${ }^{3}$ This is the assumption made by Miles and Ezzell (1985), and Arzac and Glosten (2005).
} 
Equation (10) tells us that investors would require money to hold a security with payoff equal to $\Delta D_{\mathrm{t}}$ if the expected growth rate $(\mathrm{g})$ is smaller than $\left(\mathrm{Ku}-\mathrm{R}_{\mathrm{F}}\right) /\left(1+\mathrm{R}_{\mathrm{F}}\right)$. Obviously, this is not a sensible result for most companies.

Substituting (10) in (2), we get the well-known Miles-Ezzell (ME) formula: ${ }^{4}$

$$
\operatorname{VTS}_{0}^{M E}=\frac{D_{0} R_{F} T}{(K u-g)} \frac{(1+K u)}{\left(1+R_{F}\right)}
$$

ME provides a computationally elegant solution (as shown in Arzac-Glosten, 2005), but it is not a realistic one. $D_{t}=L \cdot E_{t}$ implies that if a company has only two possible states of nature in the following period, under the worst state (low share price) the company will have to raise new equity and repay debt. Under the good state, the company will have to issue debt and pay big dividends. This is not a good description of the debt policy of most companies. ${ }^{5}$

We claim that it makes more sense to characterize the debt policy of a growing company with expected constant leverage ratio as a fixed book-value leverage ratio instead of as a fixed market-value leverage ratio for the following reasons:

- the company is more valuable: (11) is smaller than (6);

- rating agencies focus on book-value leverage ratios;

- the amount of debt does not depend on the movements of the stock market;

- it is easier to follow for non-quoted companies; and,

- the empirical evidence provides more support to the fixed book-value leverage ratio hypothesis.

Table 1 contains statistics about the financial leverage of 271 US companies: line 1 measures the leverage in book-value terms and line 2 in market-value terms. The average of the standard deviation/average of the book leverage ratio [D / (D+Ebv)] for each company was 0.34, smaller than 0.49, the same coefficient of the market-value leverage ratio [D / (D+E)]. The coefficient of the book ratio was smaller than the coefficient of the market ratio for 258 of the 271 US companies analyzed. ${ }^{6}$

\footnotetext{
${ }^{4}$ Equation (11) is identical to equations (21) in ME (1985), (13) in Arzac and Glosten (2005) and (6) in Lewellen and Emery (1986). However, Harris and Pringle (1985), Ruback (2002) and Cooper and Nyborg (2006, equation 29) propose VTS $=\mathrm{D} \mathrm{Kd} \mathrm{T} /(\mathrm{Ku}-\mathrm{g})$. This expression does not correspond to ME assumption: it is correct only in continuous time, but then $\mathrm{Ku}, \mathrm{Kd}$ and g should be expressed also in continuous time.

${ }^{5}$ Grinblatt and Titman (2002) argue that firms often pay down debt when things are going well, and do not alter debt when returns are low.

${ }^{6}$ Antoniou, Guney and Paudyal (2006, Table 2) also calculate the standard deviation and the mean of the leverage ratio measured in market-value terms and in book-value terms of companies in France, Germany and the UK. For all three countries, the average ratio of the standard deviation to the mean of the leverage ratio measured in marketvalue terms is higher than the same average in book-value terms. Xu (2006, Table I) and Flannery and Rangan (2006, Table 1), also show the standard deviation and the mean of the leverage ratio measured in market-value terms and in book-value terms (although not detailed by company): again, the ratio of standard deviation to the mean of the leverage ratio measured in market-value terms is higher than in book-value terms.
} 


\section{Table 1}

Statistics of financial leverage variables for 271 US companies of the S\&P 500, 1992-2005.

$$
\begin{gathered}
\text { Financial companies (90), zero debt companies (27), companies with no data in } 1991 \text { (101) and companies with negative } \\
\text { book-value of equity (11) were eliminated. Source of the data: Datastream. } \\
\begin{array}{r}
0.09 \text { is the average of the } 271 \text { Standard Deviations (one for each company) of } D_{t} /\left(D_{t}+E b v_{t}\right) \\
\text { Ebv = book-value of equity. } E=\text { market-value of equity. } D=\text { book-value of debt }
\end{array}
\end{gathered}
$$

\begin{tabular}{|c|c|c|c|c|c|}
\hline \multirow{2}{*}{\multicolumn{2}{|c|}{ Line }} & \multicolumn{4}{|c|}{$\begin{array}{l}\text { Average of the statistics for each } \\
\text { company }\end{array}$} \\
\hline & & $\begin{array}{l}\text { Average } \\
\text { (Av) }\end{array}$ & $\begin{array}{c}\text { Standard } \\
\text { Deviation (SD) }\end{array}$ & SD/Av. & median \\
\hline 1 & $\mathrm{D} /(\mathrm{D}+\mathrm{Ebv})$ & 0.38 & 0.09 & 0.34 & 0.38 \\
\hline 2 & $\mathrm{D} /(\mathrm{D}+\mathrm{E})$ & 0.22 & 0.07 & 0.49 & 0.21 \\
\hline
\end{tabular}

$S D / A v$. of $D /(D+E)>S D / A v$. of $D /(D+E b v)$ for 258 companies

Table 2 compares correlation coefficients of the increases of debt with the increases of assets measured in book-value (line 1) and in market-value terms (lines 2): the average and the median of the book-value correlation coefficients are higher (and the SD smaller) in book-value terms than in market-value terms. According to ME, the correlation between $\Delta \mathrm{D}$ and $\Delta(\mathrm{D}+\mathrm{E})$ should be 1 , but it is only 0.23 on average.

\section{Table 2}

\begin{tabular}{|c|c|c|c|c|c|c|c|c|}
\hline \multirow[b]{2}{*}{ Line } & \multirow[b]{2}{*}{ Correlations between: } & \multicolumn{5}{|c|}{$\begin{array}{c}\text { Statistics of the } 271 \text { correlation } \\
\text { coefficients }\end{array}$} & \multicolumn{2}{|c|}{$\begin{array}{c}\text { Number of companies } \\
\text { with }\end{array}$} \\
\hline & & Average & Median & SD & MAX & Min & Correl $<0$ & Correl $>0$ \\
\hline 1 & $\Delta \mathrm{D}_{\mathrm{t}}$ and $\Delta \mathrm{A}_{\mathrm{t}}$ & 0.71 & 0.81 & 0.28 & 1.00 & -0.45 & 8 & 263 \\
\hline 2 & $\Delta \mathrm{D}_{\mathrm{t}}$ and $\Delta(\mathrm{D}+\mathrm{E})_{\mathrm{t}}$ & 0.23 & 0.21 & 0.38 & 0.95 & -0.57 & 89 & 182 \\
\hline
\end{tabular}

Statistics of the correlations between the increases of debt and the increases of assets for 271 US companies of the S\&P 500, 1992-2005.

Average, median, standard deviation (SD), maximum and minimum of the 271 correlation coefficients (one for each company)

$A=$ book-value of assets $=$ Ebv $+\mathrm{D}=$ book-value of equity + book-value of debt.

Tables 1 and 2 permit us to conclude that debt is more correlated to the book-value of the assets than to their market-value. When managers have a target capital structure, it is usually in book-value terms (as opposed to market-value terms), in large part because this is what credit rating agencies pay attention to. Stonehill et al. (1973) provide evidence that managers do think in terms of book values. Myers (1984) argued that "companies set target book debt ratios... because book asset values are proxies for the values of assets in place". Graham and Harvey (2001) show that $81 \%$ of the CFOs in their sample had a target range for their debtequity ratio and that $39 \%$ of the companies did not have publicly-traded common stock. ${ }^{7}$ Penman, Richardson and Tuna (2005) point out that measuring leverage with market values leads to perverse results.

\footnotetext{
7 77\% of the private companies had a target range for their debt-equity ratio. It may be calculated using the survey data provided by the authors in Graham and Harvey (2003).
} 


\section{Required return to equity and WACC}

For perpetuities with a constant growth rate (g), the relationship between expected values in $t=1$ of the free cash flow (FCF) and the equity cash flow (ECF) is:

$$
\mathrm{ECF}_{0}(1+\mathrm{g})=\mathrm{FCF}_{0}(1+\mathrm{g})-\mathrm{D}_{0} \mathrm{R}_{\mathrm{F}}(1-\mathrm{T})+\mathrm{g} \mathrm{D}_{0}
$$

The value of the equity today $\left(\mathrm{E}_{0}\right)$ is equal to the present value of the expected equity cash flows. If $\mathrm{Ke}$ is the average appropriate discount rate for the expected equity cash flows, then $\mathrm{E}_{0}$ $=\mathrm{ECF}_{0}(1+\mathrm{g}) /(\mathrm{Ke}-\mathrm{g})$, and equation (12) is equivalent to:

$$
\mathrm{E}_{0}(\mathrm{Ke}-\mathrm{g})=\mathrm{Vu}_{0}(\mathrm{Ku}-\mathrm{g})-\mathrm{D}_{0}\left(\mathrm{R}_{\mathrm{F}}-\mathrm{g}\right)+\mathrm{D}_{0} \mathrm{R}_{\mathrm{F}} \mathrm{T}
$$

As, $E_{0}=\mathrm{Vu}_{0}-\mathrm{D}_{0}+\mathrm{VTS}_{0}$, the general equation for the average $\mathrm{Ke}$ is:

$$
\mathrm{Ke}=\mathrm{Ku}+\left(\mathrm{D}_{0} / \mathrm{E}_{0}\right)\left[\mathrm{Ku}-\mathrm{R}_{\mathrm{F}}(1-\mathrm{T})\right]-\left(\mathrm{VTS}_{0} / \mathrm{E}_{0}\right)(\mathrm{Ku}-\mathrm{g})
$$

Substituting (6), (8) and (11) in (14), we get Ke according to the different theories:

$$
\begin{aligned}
& \mathrm{Ke}^{\mathrm{D}=\mathrm{KEbv}}=\mathrm{Ku}+\frac{\mathrm{D}_{0}}{\mathrm{E}_{0}}\left(\mathrm{Ku}-\mathrm{R}_{\mathrm{F}}\right)(1-\mathrm{T}) \\
& \mathrm{Ke}^{\mathrm{MM}}=\mathrm{Ku}+\frac{\mathrm{D}_{0}}{\mathrm{E}_{0}}\left(\mathrm{Ku}-\mathrm{R}_{\mathrm{F}}\right) \frac{\mathrm{R}_{\mathrm{F}}(1-\mathrm{T})-\mathrm{g}}{\mathrm{R}_{\mathrm{F}}-\mathrm{g}} \\
& \mathrm{Ke}^{\mathrm{ME}}=\mathrm{Ku}+\frac{\mathrm{D}_{0}}{\mathrm{E}_{0}}\left(\mathrm{Ku}-\mathrm{R}_{\mathrm{F}}\right) \frac{1+\mathrm{R}_{\mathrm{F}}(1-\mathrm{T})}{1+\mathrm{R}_{\mathrm{F}}}
\end{aligned}
$$

Equations (15) and (16) are equal for $\mathrm{g}=0$. However, equation (16) provides a Ke smaller than $\mathrm{Ku}$ if $\mathrm{g}>\mathrm{R}_{\mathrm{F}}(1-\mathrm{T})$.

The WACC is the appropriate discount rate for the expected free cash flows, such that $\mathrm{D}_{0}+\mathrm{E}_{0}=$ $\mathrm{FCF}_{0}(1+\mathrm{g}) /(\mathrm{WACC}-\mathrm{g})$. The equation that relates the WACC and the VTS is:

$$
\mathrm{WACC}=\mathrm{Ku}-\mathrm{VTS}_{0}(\mathrm{Ku}-\mathrm{g}) /\left(\mathrm{D}_{0}+\mathrm{E}_{0}\right)
$$

Substituting (6), (8) and (11) in (18), we get the WACC according to the different theorie: ${ }^{8}$

$$
\begin{aligned}
& \mathrm{WACC}^{\mathrm{D}=\mathrm{KEbv}}=\mathrm{Ku}-\frac{\mathrm{D}_{0} \mathrm{~T}}{\left(\mathrm{D}_{0}+\mathrm{E}_{0}\right)} K u \\
& \mathrm{WACC}^{\mathrm{MM}}=\mathrm{Ku}-\frac{\mathrm{D}_{0} \mathrm{~T}}{\left(\mathrm{D}_{0}+\mathrm{E}_{0}\right)} \frac{\mathrm{R}_{\mathrm{F}}(\mathrm{K}-\mathrm{g})}{\left(\mathrm{R}_{\mathrm{F}}-\mathrm{g}\right)} \\
& \mathrm{WACC}^{\mathrm{ME}}=\mathrm{Ku}-\frac{\mathrm{D}_{0} \mathrm{~T}}{\left(\mathrm{D}_{0}+\mathrm{E}_{0}\right)} \frac{\mathrm{R}_{\mathrm{F}}(1+\mathrm{Ku})}{\left(1+\mathrm{R}_{\mathrm{F}}\right)}
\end{aligned}
$$

\footnotetext{
${ }^{8}$ (19) is equal to formulae (20) of ME (1980), (2) of Lewellen and Emery (1986), and (18) of Stanton and Seasholes (2005). 


\section{A numerical example}

Table 3 contains the main valuation results for a constant company growing at a constant rate $(3 \%)$. One of the results has no economic sense: according to MM, Ke (7.65\%) is smaller than $\mathrm{Ku}(9 \%)$.

\section{Table 3}

Example. Valuation of a constant growing company

$$
A_{0}=1,000 ; D_{0}=750 ; P^{P T u_{0}}=100 ; R_{F}=4 \% ; K u=9 \% ; T=40 \% ; g=3 \% ; v_{0}=1,216.67
$$

\begin{tabular}{|l|c|c|c|}
\hline & $\begin{array}{c}\text { Constant book- } \\
\text { value leverage }\end{array}$ & Modigliani-Miller & Miles-Ezzell \\
\hline $\mathrm{VTS}_{0}$ & 450 & 1,200 & 209.62 \\
\hline $\mathrm{PV}\left[\Delta \mathrm{D}_{\mathrm{t}}\right]$ & 375 & 2,250 & -225.96 \\
\hline Equity value $\left(\mathrm{E}_{0}\right)$ & 916.67 & $1,666.67$ & 676.28 \\
\hline $\mathrm{Ke}$ & $11.45 \%$ & $7.65 \%$ & $14.46 \%$ \\
\hline WACC & $7.38 \%$ & $6.02 \%$ & $8.12 \%$ \\
\hline
\end{tabular}

Figure 1 shows the Present Value of the expected increases of debt according to the three theories as a function of growth. According to ME the present value of the increases of debt is negative if the growth rate $(\mathrm{g})$ is lower than $4.8 \%$.

\section{Figure 1}

Present value of the expected increases of debt as a function of growth

$$
\mathrm{A}_{0}=1,000 ; \mathrm{D}_{0}=750 ; \mathrm{PATu}_{0}=100 ; \mathrm{R}_{\mathrm{F}}=4 \% ; \mathrm{Ku}=9 \% ; \mathrm{T}=40 \%
$$

$\mathrm{PV}$ (incD)mm corresponds to equation (7); PV(incD)me corresponds to equation (10); PV(incD)cbvl corresponds to equation (5)

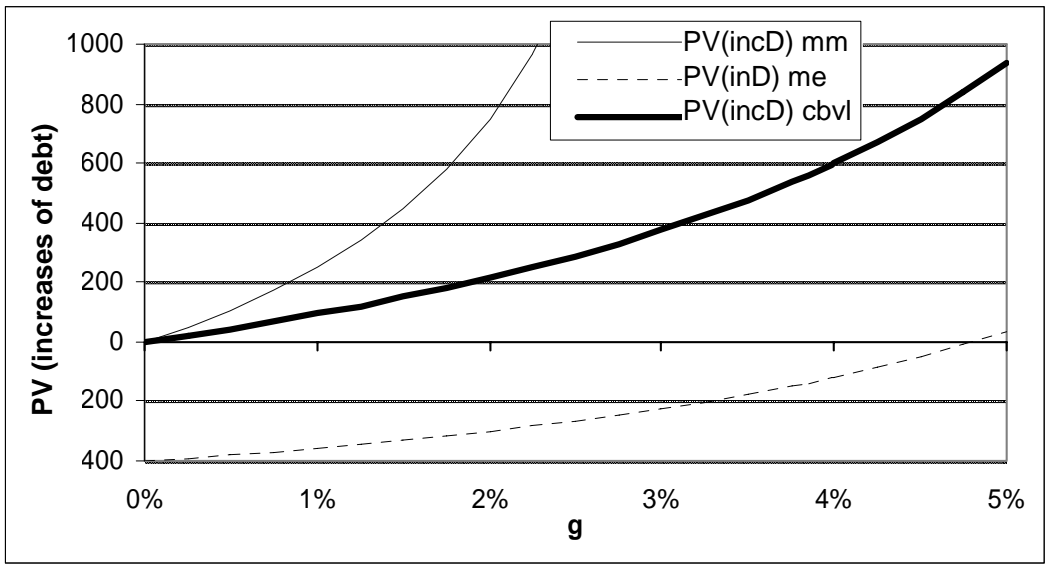

Figure 2 shows the WACC as a function of growth: according to MM WACC is a decreasing function of g. The constant leverage in book-value terms provides results that lie between those of MM and ME. 


\section{Figure 2}

WACC as a function of growth

$A_{0}=1,000 ; D_{0}=750 ; P^{P A T u}=100 ; R_{F}=4 \% ; K u=9 \% ; T=40 \%$

WACCmm corresponds to equation (20); WACCme corresponds to equation (21); WACCcbvl corresponds to equation (19)

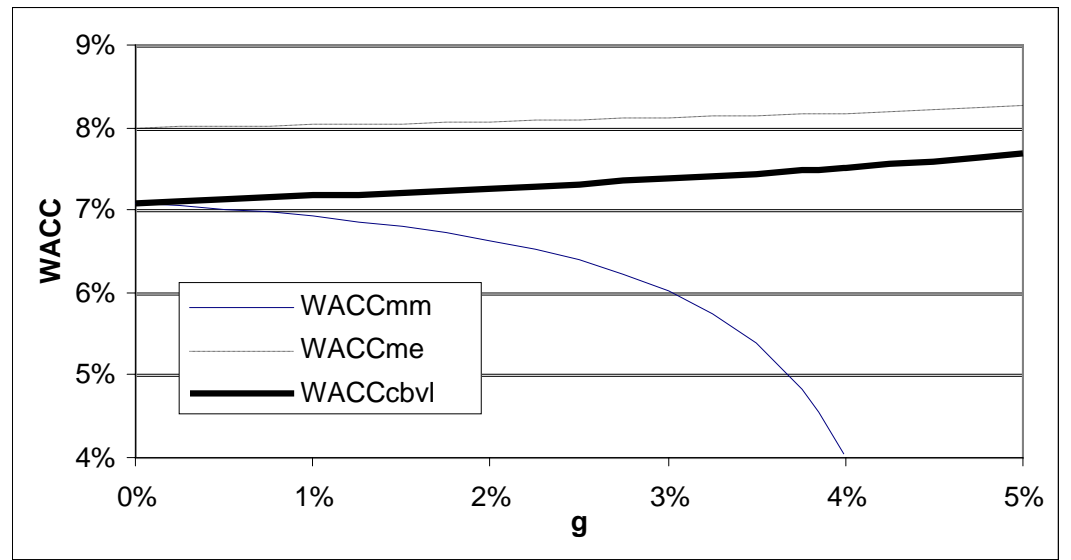

With the constant growth model the market-to-book ratio is also constant, since all parameters are constant, and so the market and book debt ratios are constant through time. However, the riskiness of the future debt is completely different: under ME (debt is determined by a marketvalue ratio) debt and tax shields are riskier than if debt is determined by a book-value ratio.

\section{The correlation between the tax shields and the free cash flow}

The relationship between the dividends (equity cash flows) and the free cash flow is:

$$
\operatorname{Div}_{\mathrm{t}}=\mathrm{FCF}_{\mathrm{t}}-\mathrm{D}_{\mathrm{t}-1} \mathrm{R}_{\mathrm{F}}(1-\mathrm{T})+\Delta \mathrm{D}_{\mathrm{t}}
$$

As managers do not like to change the dividends much, it is reasonable to expect that most companies will show a negative correlation between the FCF and the $\Delta \mathrm{D}$. Table 4 supports that prediction: 265 US companies (out of 271) have a negative correlation between $\triangle \mathrm{D}$ and FCF in the period 1991-2005, and the negative correlation is very strong. On the other hand, the correlation between $\Delta \mathrm{D}$ and $\Delta \mathrm{A}$ (shown in Table 2) is strongly positive. If debt is proportional to the book-value of equity, it is also proportional to the book-value of assets (A): D = LA; and $\Delta \mathrm{D}_{\mathrm{t}}=\mathrm{L} \Delta \mathrm{A}_{\mathrm{t}}$. Substituting $\Delta \mathrm{D}_{\mathrm{t}}$ by $\mathrm{L} \Delta \mathrm{A}_{\mathrm{t}}$ in (22), we get:

$$
\Delta \mathrm{D}_{\mathrm{t}}(1-\mathrm{L}) / \mathrm{L}=\mathrm{PATu}_{\mathrm{t}}-\operatorname{Div}_{\mathrm{t}}-\mathrm{D}_{\mathrm{t}-1} \mathrm{R}_{\mathrm{F}}(1-\mathrm{T})
$$




\section{Table 4}

Statistics of the correlation between PATu, FCF and $\triangle \mathrm{A}$ and other variables for 271 US companies of the S\&P 500, 1992-2005

Average, median, standard deviation (SD), maximum and minimum of the 271 correlation coefficients (one for each company)

\begin{tabular}{|c|c|c|c|c|c|c|c|}
\cline { 2 - 8 } & \multicolumn{4}{c|}{$\begin{array}{c}\text { Statistics of the 271 correlation } \\
\text { coefficients }\end{array}$} & \multicolumn{2}{c|}{$\begin{array}{c}\text { Number of companies } \\
\text { with }\end{array}$} \\
\cline { 2 - 8 } Correlations between: & Average & Median & SD & MAX & Min & Correl < 0 & Correl > $\mathbf{~}$ \\
\hline$\Delta \mathrm{D}_{\mathrm{t}}$ and $\mathrm{FCF}$ & $-\mathbf{0 , 7 6}$ & $-0,86$ & 0,26 & 0,43 & $-1,00$ & $\mathbf{2 6 5}$ & 6 \\
\hline$\Delta \mathrm{A} / \mathrm{A}$ and $\mathrm{FCF} / \mathrm{A}$ & $-\mathbf{0 , 9 1}$ & $-0,97$ & 0,15 & 0,43 & $-1,00$ & $\mathbf{2 7 0}$ & 1 \\
\hline$\Delta \mathrm{A} / \mathrm{A}$ and PATu/A & 0,41 & 0,50 & 0,33 & 0,94 & $-0,74$ & 33 & $\mathbf{2 3 8}$ \\
\hline $\mathrm{FCF} / \mathrm{A}$ and $\mathrm{PATu} / \mathrm{A}$ & $-0,11$ & $-0,13$ & 0,38 & 0,89 & $-0,85$ & 176 & 95 \\
\hline interest $\mathrm{t}_{\mathrm{t}}$ and $\mathrm{FCF}_{\mathrm{t}-1}$ & $-0,21$ & $-0,25$ & 0,30 & 0,74 & $-0,80$ & $\mathbf{2 1 2}$ & 59 \\
\hline$\Delta \mathrm{D}_{\mathrm{t}} / \mathrm{A}_{\mathrm{t}}$ and $\mathrm{PATu} / \mathrm{A}_{\mathrm{t}}$ & 0,18 & 0,23 & 0,34 & 0,89 & $-0,83$ & 81 & $\mathbf{1 9 0}$ \\
\hline
\end{tabular}

Statistics of PATu, FCF and $\triangle \mathrm{A}$

0.07 is the average of the $271 \mathrm{SD}$ of $\left(\mathrm{PATu} / \mathrm{A}_{\mathrm{t}-1}\right)$ (one for each company)

\begin{tabular}{|l|c|c|c|c|c|c|c|c|}
\cline { 2 - 9 } \multicolumn{1}{c|}{} & \multicolumn{4}{c|}{ Average of the statistics for each company } & \multicolumn{2}{c|}{$\begin{array}{c}\text { Number of companies } \\
\text { with average }\end{array}$} \\
\cline { 2 - 9 } & $\begin{array}{c}\text { Average } \\
\text { (Av) }\end{array}$ & $\begin{array}{c}\text { Standard } \\
\text { Deviation (SD) }\end{array}$ & SD/Av. & Median & MAX & Min & $<0$ & $>\mathbf{0}$ \\
\hline PATu/A & 0.13 & 0.07 & 0.64 & 0.13 & 0.26 & 0.00 & 2 & 269 \\
\hline FCF/A & -0.02 & 0.24 & 1.27 & 0.04 & 0.24 & -0.64 & 126 & 145 \\
\hline$\Delta \mathrm{A} / \mathrm{A}$ & 0.15 & 0.26 & 2.39 & 0.09 & 0.80 & -0.14 & 7 & 264 \\
\hline
\end{tabular}

Correlation between $\mathrm{SD}$ of $\mathrm{FCF} / \mathrm{A}$ and $\mathrm{SD}$ of $\triangle \mathrm{A} / \mathrm{A}=0.98$

In $t-1, D_{t-1} R_{F}(1-T)$ is known and $\operatorname{Div}_{t}$ has already been announced. Consequently, $\Delta D_{t}$ and PATu $u_{t}$ are positively correlated. If $\Delta \mathrm{D}_{\mathrm{t}}$ was a multiple of $\Delta \mathrm{A}_{\mathrm{t}}$, then $\Delta \mathrm{D}_{\mathrm{t}}$ should be also positively correlated with $\mathrm{PATu}_{\mathrm{t}}$. Table 4 tells us that 190 companies present a positive correlation between $\Delta D_{t} / A_{t}$ and $P A T u_{t} / A_{t}$, although these correlation coefficients are smaller than the ones between $\Delta \mathrm{A}_{\mathrm{t}}$ and PATu $\mathrm{u}_{\mathrm{t}}$.

\section{Conclusions}

The value of tax shields (VTS) defines the increase in the company's value as a result of the tax saving obtained by the payment of interest. However, there is no consensus in existing literature regarding the correct way to compute the VTS. Most authors think of calculating the VTS in terms of the appropriate present value of the tax savings due to interest payments on debt, but Modigliani and Miller (1963, MM) propose discounting the tax savings at the risk-free rate $\left(\mathrm{R}_{\mathrm{F}}\right){ }^{9}$ and Miles and Ezzell $(1980,1985, \mathrm{ME})$ propose discounting these tax savings the first

\footnotetext{
${ }^{9}$ Myers (1974), Luehrman (1997), and Damodaran (2006, page 212) propose to discount it at the cost of debt (Kd). Brealey and Myers (2000, page 558) propose using the "effective tax shield on interest" (a figure lower than the corporate tax rate that takes account of the years in which the firm does not pay taxes), but they admit that "we were unable to pin down an exact figure for the effective tax shield on interest". Damodaran (2006, page 215) proposes to deduct the present value of the bankruptcy cost.
} 
year at the cost of debt and the following years at Ku. Reflecting this lack of consensus, Copeland et al. (2000, page 482) claim that "the finance literature does not provide a clear answer about which discount rate for the tax benefit of interest is theoretically correct." Many authors [including Taggart (1991), Inselbag and Kaufold (1997), Booth (2002), Cooper and Nyborg (2006), Oded and Michel (2006), Farber et al. (2006)] consider that debt policy may only be framed in terms of maintaining a fixed market-value debt ratio (ME) or a fixed dollar amount of debt (MM).

MM and ME are two extreme cases that are not valid for most companies: MM should be used when the company has a preset amount of debt; ME should be used only when debt will be always a multiple of the equity market-value. We develop valuation formulae for companies that maintain a fixed book-value leverage ratio and argue that, for most companies, and especially when calculating residual values, this assumption is more realistic than those of MM and ME. We obtain an intermediate value between those of MM and ME.

If a company targets its leverage in market-value terms, it has less value than if it targets the leverage in book-value terms. Why, then, would a manager target leverage in market-value terms? Nevertheless, many authors identify constant leverage with a constant market leverage ratio.

Flannery and Rangan (2006) point out that "finance theory tends to downplay the importance of book ratios", and we argue that it makes more sense to characterize the debt policy of a company with an expected constant leverage ratio as a fixed book-value leverage ratio (instead of as a fixed market-value leverage ratio). The empirical evidence also provides more support for the fixed book-value leverage ratio hypothesis. It means that when managers have a target capital structure, it is usually in book-value terms (as opposed to market-value terms), in large part because this is what credit rating agencies pay attention to. 


\section{References}

Antoniou, A., Y. Guney and K. Paudyal (2006), "The Determinants of Debt Maturity Structure: Evidence from France, Germany and the UK," European Financial Management 12/ 2, pp. 161-194.

Arzac, E.R. and L.R. Glosten (2005), “A Reconsideration of Tax Shield Valuation," European Financial Management, 11/4, pp. 453-461.

Blume, M., F. Lim, and A. MacKinlay (1998), "The Declining Credit Quality of U.S. Corporate Debt: Myth or Reality," Journal of Finance 53, pp. 1389-1413.

Booth, L. (2002), "Finding Value Where None Exists: Pitfalls in Using Adjusted Present Value," Journal of Applied Corporate Finance, 15/1, pp. 8-17.

Booth, L. (2007), “Capital Cash Flows, APV and Valuation,” European Financial Management, $13 / 1$, forthcoming.

Brealey, R.A. and S.C. Myers (2000), "Principles of Corporate Finance," $6^{\text {th }}$ edition, McGrawHill, New York.

Cooper, I. A. and K. G. Nyborg (2006), "The Value of Tax Shields IS Equal to the Present Value of Tax Shields," Journal of Financial Economics, 81, pp. 215-225.

Copeland, T. E., T. Koller, and J. Murrin (2000), "Valuation: Measuring and Managing the Value of Companies," $3^{\text {rd }}$ edition, Wiley, New York.

Damodaran, A. (2006), "Damodaran on Valuation," $2^{\text {nd }}$ edition, John Wiley and Sons, New York, $1^{\text {st }}$ edition: (1994).

Farber, A., R. L. Gillet, and A. Szafarz (2006), “A General Formula for the WACC,” International Journal of Business, 11/2, pp. 211-218.

Fernández, P. (2004), "The Value of Tax Shields is not Equal to the Present Value of Tax Shields, Journal of Financial Economics, 73/1, pp.145-165.

Flannery, M. J. and K. P. Rangan (2006), "Partial Adjustment Toward Target Capital Structures," Journal of Financial Economics, 79, pp. 469-506.

Graham, J.R. and C.R. Harvey (2001), "The Theory and Practice of Corporate Finance: Evidence from the Field," Journal of Financial Economics, 60/2, pp.187-243.

Grinblatt, M. and S. Titman (2002), "Financial Markets and Corporate Strategy," Irwin/McGraw-Hill, $2^{\text {nd }}$ ed. Burr-Ride, Il.

Harris, R.S. and J.J. Pringle (1985), "Risk-adjusted discount rates extensions from the averagerisk case," Journal of Financial Research, 8, pp. 237-244.

Inselbag, I. and H. Kaufold (1997), "Two DCF Approaches for Valuing Companies under Alternative Financing Strategies and How to Choose between Them," Journal of Applied Corporate Finance, 10, pp. 114-122.

Lewellen, W.G. and D.R. Emery (1986), "Corporate Debt Management and the Value of the Firm," Journal of Financial and Quantitative Analysis, 21/4, pp. 415-426. 
Luehrman, T. (1997), "Using APV: a Better Tool for Valuing Operations," Harvard Business Review, 75, pp. 145-154.

Massari, M., F. Roncaglio, and L. Zanetti (2007), "On the Equivalence Between the APV and the WACC Approach in a Growing Leveraged Firm," European Financial Management, forthcoming.

Miles, J.A. and J.R. Ezzell (1980), "The Weighted Average Cost of Capital, Perfect Capital Markets and Project Life: A Clarification," Journal of Financial and Quantitative Analysis, 15, pp. 719-730.

Miles, J.A. and J.R. Ezzell (1985), “Reformulating Tax Shield Valuation: A Note," Journal of Finance, 40/5, pp. 1485-1492.

Modigliani, F. and M. Miller (1963), "Corporate Income Taxes and the Cost of Capital: a Correction," American Economic Review, 53, pp. 433-443.

Myers, S.C. (1974), "Interactions of Corporate Financing and Investment Decisions Implications for Capital Budgeting," Journal of Finance, 29, pp. 1-25.

Myers, S.C. (1984), “The Capital Structure Puzzle,” Journal of Finance, 39/3, pp. 575-592.

Oded, J. and A. Michel (2006), "Reconciling Valuation Methodologies: The Importance of a Company’s Debt Rebalancing Policy,” Boston University, unpublished paper.

Penman, S. H., S.A. Richardson, and A.I. Tuna (2005), ”The Book-to-Price Effect in Stock Returns: Accounting for Leverage," unpublished paper.

Ruback, R. (2002), "Capital Cash Flows: A Simple Approach to Valuing Risky Cash Flows," Financial Management, 31, pp. 85-103.

Standard and Poor's (2006), “Corporate Ratings Criteria," downloadable in http://www2.standardandpoors.com/spf/pdf/fixedincome/corporateratings_2006.pdf

Stanton, R. and M.S. Seasholes (2005), "The assumptions and Math Behind WACC and APV Calculations", unpublished paper, U.C. Berkeley.

Stonehill, A., T. Beekhuisen, R. Wright, L. Remmers, N. Toy, A. Pares, A. Shapiro, D. Egan, and T. Bates (1973), "Determinants of Corporate Financial Structure: A Survey of Practice in Five Countries," unpublished paper.

Taggart, R.A. Jr. (1991), "Consistent Valuation and Cost of Capital. Expressions with Corporate and Personal Taxes," Financial Management, 20, pp. 8-20.

Xu, Z. (2006), “Do Companies Adjust Toward a Target Leverage Level?,” unpublished paper. 